\title{
Family Control and Earnings Management: An Empirical Analysis of the Lebanese Banking Sector
}

\author{
Ekramy S. Mokhtar (Corresponding author) \\ Faculty of Business Administration, Beirut Arab University, Beirut, Lebanon \\ E-mail: e.mokhtar@bau.edu.lb
}

Ali M. Elharidy

Faculty of Commerce, Damanhour University, Al-Bohira, Egypt

Brighton Business school, University of Brighton, UK

Received: September 16, 2019 Accepted: October 18, 2019 Published: November 6, 2019

doi:10.5296/ijafr.v9i4.15446

URL: https://doi.org/10.5296/ijafr.v9i4.15446

\begin{abstract}
This study aims to examine the relationship between board of directors' characteristics, family control and earnings management practices in Lebanese commercial banks during 2008 to 2016. The characteristics of the board of directors are board size and role duality. Also, the study aims to identify earnings management practices during and after the global financial crisis. Earnings management was measured using discretionary accruals estimated by loan losses provision. The population for the study consists of Lebanese commercial banks registered with the Banque du Liban, which provided 182 bank/year observations during the study period. The results of the study indicate that Lebanese commercial banks with a relatively larger family control are more involved in earnings management practices. The study demonstrates that self-interest overrides common interests, leading the controlling family to maximize its own benefits at the expense of minority owners, resulting in more earnings management practices. In addition, capital adequacy and board size have significant positive influence on earnings management. Earnings management practices were not affected by role duality and bank size. Further, maintaining profitability was found to have a significant impact on earnings management practices. Finally, the results of the study indicate that Lebanese commercial banks became involved in earnings management practices after the global financial crisis compared to the period during the crisis.
\end{abstract}

Keywords: Family control, Board of directors' characteristics, Earnings management 


\section{Introduction}

Financial statements aim to provide relevant and faithful representative information about the economic events of the entity. Such information should be high quality, consistent and comparable in order to increases investor confidence in reported information and supports the efficiency of financial markets. However, accounting standards offer great flexibility, which provides managers with considerable discretion in determining reported earnings in the financial statements. This discretion may negatively influence the quality of the financial reporting (Saleh et al., 2005). Earnings management occurs when managers exercise accounting choice in preparing financial reports and structuring transactions (Agarwal et al., 2007). Accounting accruals provide managers with a large extent of discretion in determining the amount and timing of expenses and income (Xie et al., 2003). Due to scandals of global companies, earnings management has become a fruitful area for several accounting studies (Abdul Rahman and Ali, 2006; Jouber and Fakhfakh, 2012; Mohamad et al., 2012).

The banking sector is an important economic sector in a country. Fluctuations in the performance of this sector may bring regulatory intervention. In addition, corporate governance in the banking sector is seen as an important element for assessing and controlling management decisions (Leventis and Dimitropoulos, 2012). However, bank's management may manipulate earnings by influencing the amount of loan losses recognized in accounting records even under scrutiny by regulatory agencies (Elleuch, 2015). For example, during periods of declining income, management may increase earnings by delaying the recognition of loan losses (Cornett et al., 2009). One of the key reasons behind earnings management in the banking sector is to meet regulatory requirements such as capital adequacy ratio (Elleuch, 2015). Regulatory requirements are imposed on banking activities in order to protect investors, depositors, the general public, and the economy. Although various studies that examine the role of corporate governance in reducing earnings management, there is still a paucity of studies that examine the relationship between corporate governance and earnings management in the banking sector. Earnings management practices in the banking sector have not been adequately studied in accounting literature (Cornett et al., 2009; Kanagaretnam et al., 2010; Leventis and Dimitropoulos, 2012). Finally, the 2008 global financial crisis can help in identifying the changes in earnings management practices during and after the crisis, which is relatively rare in current earnings management literature (Arthur et al., 2015; Filip and Raffournier, 2014).

Family businesses are the main pillars of socioeconomic development and value creation in different countries. Bassemir and Novotny (2018) argue that private firms controlled by family ownership exhibit low stewardship and valuation problems because of the tight grip of family owners. In Lebanon, family business is considered one of the most important economic forms of business organizations, with increasing dependence on family members in running and managing the entity (Fahed-Sreih et al., 2009). Although there is an increasing attention devoted to family firms, the impact of family control on earnings management still limited (Paiva et al., 2019; Prencipe and Bar-Yosef, 2011). According to Chi et al. (2015), family control is a cause for the emergence of a new agency conflict; the principal-principal conflict. This agency problem refers to the conflict of interest between the controlling family 
and minority shareholders. Family-controlled firms are characterized by a long-term ownership orientation and close relationships between shareholders and executives (Bonacchi et al. 2018). Duréndez and Madrid-Guijarro (2018) indicate that family long-term 'experience' provides a means to curb earnings management practices and improve the quality of financial reporting, whereas it limits the power inside the firm. Lebanon is an interesting setting to examine the impact of family control on earning management considering the weak legal system, ineffective corporate governance and the non-compliance with accounting standards (World Bank, 2003) and high firm political affiliation. Accounting literature argue that political affiliation may influence earnings management practices (Jacoby et al., 2019). Lebanon suffers from some political conflicts which results in policy uncertainty which in turn affects earnings management (Yung and Root, 2019). Lebanon is chosen for this study because of the development of the banking system as one of the most important banking sectors in the Middle East. This research attempts to answer the following research questions:

1. Is there a relationship between the level of family control and earnings management practices in Lebanese commercial banks?

2. Is there a relationship between the role duality and earnings management practices in Lebanese commercial banks?

3. Is there a relationship between capital adequacy and earnings management practices in Lebanese commercial banks?

4. Is there a relationship between board size and earnings management practices in Lebanese commercial banks?

The main objective of this research is to estimate the abnormal discretionary component of loan loss provision as a proxy of earning management practices and examine earnings management practices using the variations in family control, role duality, capital adequacy ratio and board size. To achieve these research objectives, the study will be organized as follows: section two discusses the theoretical framework for earnings management. Section three reviews previous studies and derives the research hypotheses. Section four presents the research design and methodology. Section five includes the discussion of the results. Finally, section six presents the research conclusions, limitations and future research.

\section{Earnings Management: A Conceptual Background}

This section presents the theoretical background of earnings management as relevant to the current study. It starts by defining earnings management and the motives and discuss the use of loan loss provision (LLP) in the banking sector to manipulate earnings.

\subsection{Earnings Management Definition and Motivations}

Beneish (2001) points out that there is no agreement among researchers on the definition of earnings management. For example, Schipper (1989, p. 92) defines earnings management as "a purposeful intervention in the external financial reporting process, with the intent of obtaining some private gain... a minor extension to the definition would encompass "real" earnings management, accomplished by timing investment or financing decisions to alter 
reported earnings or some subset of it.". In the same vein, Healy and Wahlen (1999, p.368) argue that earnings management takes place when "managers use judgment in financial reporting and in structuring transactions to alter financial reports to either mislead some stakeholders about the underlying economic performance of the company or to influence contractual outcomes that depend on reported accounting numbers.." Furthermore, Noronha et al. (2008, p. 370) define earnings management as "a set of accounting choices from within GAAP to violating GAAP."

These definitions indicate that earnings management is limited to practices related to financial reporting within generally accepted accounting principles (GAAP) (Dechow et al., 1996). Unlike financial reporting fraud, earnings management involves the selection of accounting alternatives and estimates that comply with GAAP in a manner that makes it difficult to identify earnings management practices (Koumanakos et al., 2005). Furthermore, these definitions indicate that earnings management may take place in financial reports, including restructuring of transactions or timing of investment and financing decisions. Discretionary expenditure may be deferred or accelerated over a short period around the end of the fiscal year; known as real earnings management (Beneish, 2001). Earnings management practices can be divided into four groups; the first group represents neutral accounting practices that are within generally accepted accounting principles; the second group is conservative accounting practice aimed at reducing income; and the third group is aggressive accounting practice that aim to increase income. The fourth group is accounting practice that depart from generally accepted accounting principle, leading to fraudulent financial reporting (Dechow and Skinner, 2000). The primary purpose of earnings management is to hide the company's deteriorating performance, although this does not preclude the possibility of earnings management in order to improve accounting earnings (Beneish, 2001).

Therefore, we argue that earnings management is the management practices resulting from the flexibility in accounting standards. It provides management with the freedom to determine the amount and timing of recognizing income and expenses. In other words, these practices result from management ability to influence investment and financing decisions.

These practices take place as a result of a number of motives. Healy and Wahlen (1999) indicate several motives for earnings management practices such as motives associated with contracts, motives associated with managerial incentives, motives associated with the capital market and motives associated with regulation.

Regarding contractual motives, accounting data is used to control and regulate contracting between the firm and other stakeholders. External contracts such as debt contracts may force managers to manage earnings to meet the requirements of those contracts. For example, DeFond and Jiambalvo (1994) suggest that firms may increase earnings management practices in the year immediately prior to the year in which the terms of debt contracts are dishonored. So, debt contracts are drafted in such a way to limit managerial actions that benefit owners to the detriment of creditors. 
Regarding managerial incentives motives, management compensation contracts are based on management performance that measured using accounting data. Therefore, managers may attempt to convert profits from future periods to the current period to increase their bonuses and job security.

Regarding capital market motives, the increased use of accounting information by investors and financial analysts to evaluate stocks may create incentives for managers to manipulate and manage earnings in order to influence short-term stock prices. For example, companies may manage earnings in order to reduce the volatility of earnings and thus maximize stock prices, as sharp fluctuations in profits may reflect the risks to which the company may be exposed. Consequently, stocks may lose value compared to those of other companies that have stable earnings pattern (Abdelghany, 2005).

Regarding regulatory motives, Abdelghany (2005) points out that companies may have a motive to lower their earnings to reduce political costs associated with high profits. For example, high oil prices could create an incentive for companies to manage earnings to avoid government intervention, introduction of new taxes or price controls. Key (1997) points out that companies operating in the cable television industry manage their earnings to avoid regulatory interference and to avoid any potential legislation issued by regulators. Elleuch (2015) suggests that banks may manage their earnings to reduce political costs and avoid penalties for non-compliance with minimum capital requirements.

\subsection{Loan Loss Provision in the Banking Sector}

Loan loss provision is considered to be the largest source of accruals in the banking sector and have a significant impact on bank's earnings and capital adequacy ratio (Ahmed et al., 1999). The focus on the banking sector facilitates the development of industry-related models to study accounting choice using loan loss provision (LLP) (Beatty et al., 2002). LLP reflects management's estimate of the level of expected future loan losses that may occur if the borrower stops payment. Therefore, if the level of the LLP is not at the appropriate level, it means that the bank's capital will decrease; indicating that the capital adequacy ratio may not be sufficient to absorb expected losses (Cornett et al., 2009).

Bank management uses LLP to manage capital in accordance with regulatory requirements and to communicate information about expected future results to capital markets (Ahmed et al., 1999). Bank managers can also avoid reporting a slight decrease in earnings by reducing the value of loan losses or by recognizing more (less) gains (losses) on sale of investments (Beatty et al., 2002).

Bank managers may have private information about credit risk in the loan portfolio and may therefore use personal judgment to estimate loan losses. Taking into account information asymmetry, it will be difficult for investors, regulators and auditors to obtain all information that the bank's management possesses (Cornett et al., 2009). Therefore, bank managers can exercise accounting choice to influence the timing of loan losses recognition (Wahlen, 1994). They can also influence the level of loan losses itself. They can reduce (increase) the level of loan losses in years of poor (good) financial performance which leads to improving profits 
and vice versa (Ismail et al., 2005). Thus, there are many incentives for bank managers to use LLP in earnings management (Ahmed et al., 1999). With management's opportunistic behavior and the prevalence of loan insurance, depositors will be less inclined to control bank management further allowing management to manipulate and manage earnings (Elleuch, 2015).

LLP may be interpreted by the market as a reassessment of bank managers' private information about expected future earnings because investors base their interpretation of unexpected loan loss provision on unexpected changes in non-performing. Therefore, investors may interpret the increase in LLP as good news about future cash flows and stock returns (Wahlen, 1994).

We argue that using the specific accruals approach is appropriate for the purpose of this study. LLP is an important source of earnings management in the banking sector as previous studies indicate that banks use it in earnings management (Cornett et al., 2009; Healy and Wahlen, 1999), and it is more prone to managerial discretion as it represents a large proportion of accruals (Ahmed et al., 1999). It is used to meet capital adequacy requirements and to signal information to capital markets about managers' expectations of expected future earnings and cash flows. According to McNichols (2000), the use of specific accruals will contribute to earnings management literature.

\section{Literature Review and Hypotheses Development}

This section presents a review of previous studies regarding the relationship between family control, role duality, capital adequacy and earnings management practices (3.1). Based on this review, research hypotheses are derived in section (3.2).

\subsection{Previous Literature}

Since 1980s, researchers have attempted to develop models of discretionary accruals such as Healy (1985), DeAngelo (1986), and Jones model (1991) which developed in Dechow et al. (1995). Accounting research then proceeded to explore the potential role of corporate governance in reducing earnings management practices (Abdul Rahman and Ali, 2006; Jouber and Fakhfakh, 2012; Mohamad et al., 2012; Xie et al., 2003).

Earnings management practices have been the subject of interest in many accounting studies, and this interest has been increased with the emerge of economic crises and their negative impact on investor confidence in the quality of financial reports (Argile's-Bosch et al., 2015). According to agency theory, the separation of ownership and management leads to opportunistic behavior of the managers (agent) by maximizing their personal interest at the expense of the owners (principal) (Jensen and Meckling, 1976). Management will act with a self-interest incentive to find opportunities to manage earnings (Klein, 2002). Information asymmetry between management and owners will create an incentive for managers to report accounting information that may deviate from the substance of key economic transactions to maximize benefits at the expense of owners and creditors (Wang, 2006). 


\section{MInstitute ${ }^{\text {Mech }}$}

International Journal of Accounting and Financial Reporting

ISSN 2162-3082

Corporate governance received increased attention in accounting research due to its role in improving investor confidence and supporting financial reporting integrity, reducing information asymmetry and resolving the conflict of interest between owners and managers (Mohamad et al., 2012). Corporate governance enhances investors' confidence in the reliability of earnings as an indicator of corporate financial performance (Roodposhti and Chashmi, 2011). Therefore, many corporate governance recommendations - such as the UK's Cadbury Commission - have identified the quality of financial reporting and the minimization of earnings management as important areas of effective corporate governance. It also emphasized the role of the board of directors (BOD) in reducing earnings management practices (Al-Fayoumi et al. 2010; Peasnell et al., 2000). Weak corporate governance leads to more earnings management and thus reduces the quality of financial reporting (Jiang et al., 2008).

Previous studies examined the impact of BOD characteristics such as BOD size (Abdul Rahman and Ali, 2006; Alves, 2011; Dimitropoulos and Asteriou, 2009); BOD independence (Klein, 2002; Xie et al. 2003), role duality (Mansor et al., 2013; Chi et al., 2015; Mohamad et al. 2012) and family control (Jaggi and Tsui, 2007; Machuga and Teitel, 2009; Wang, 2006) in reducing earnings management practices.

A study by Cornett et al. (2009) examine the relationship between corporate governance and earnings management in 56 US banks during the period 1994-2002. Earnings management was measured by LLP and realized gains (losses) on investments. The results indicate that board independence and bank size are factors that limit earnings management practices geared towards increasing income, and role duality increases the likelihood of management involvement in earnings management practices.

Leventis and Dimitropoulos (2012) test the role of corporate governance in mitigating earnings management using a sample of 315 US financial institutions registered on the stock exchange during the period 2003 to 2008 . Earnings management was measured using three approaches: reporting small positive earnings, the discretionary portion of LLP and investment gains and losses, and total discretionary accruals. Corporate governance was measured by a 67-item index in accordance with the requirements of the Sarbanes-Oxley Act. The results of the study suggest an inverse relationship between corporate governance and earnings management. Companies with high ratings on the corporate governance index are less inclined to engage in earnings management practices.

In a recent study, Taktak and Mbarki (2014) examine the relationship between board characteristics, audit quality and earnings management in a sample of 7 Tunisian banks during 2003-2007. Earnings management practices have been measured by discretionary accruals in LLP. Results indicate a positive relationship between role duality and earnings management. Contrary to expectations, there is a signification positive association auditor's affiliation with big four audit firms and earnings management. In the case of a joint audit between a local firm and another of the big four firms, it adversely affects earnings management practices. 


\section{Mll Macrothink}

International Journal of Accounting and Financial Reporting

ISSN 2162-3082

2019, Vol. 9, No. 4

Focusing on family business, Mansor et al. (2013) examine the impact of corporate governance on earning management in Malaysian family and non-family owned companies in 2008. The result shows that different corporate governance mechanisms may have different impact on earnings management depending on the existence and absence of family ownership. In the same vein, Chi et al. (2015) investigate the influence of family control on earnings management in Taiwan. Using a sample of 379 listed high-technology firms from 2006 to 2012. The results indicate a positive association between family control and earnings management. This means that firms with high family control exercise more earnings management. Moreover, the interaction between family control and role duality is positively associated with earnings management while the interaction between board independence and family control is negatively associated with earnings management.

Reviewing the literature indicates a research gap in the accounting literature due to focusing on earnings management practices in developed countries while far fewer studies deal with these practices in developing countries. This situation has led to a lack of adequate understanding of the determinants of these accounting practices in developing countries since relations that appear adequate in developed countries may not be the same in less developed countries.

We believe that despite the numerous studies that investigate earnings management practices in the non-financial sector, there is still a paucity of studies that examine the determinants of earnings management in the banking sector (Leventis and Dimitropoulos, 2012). In addition, there is a lack of studies conducted during and after economic crises. This study will attempt to address these research gaps in earnings management literature.

\subsection{Research Hypotheses}

Based on previous studies and theoretical framework of the agency theory, a number of hypotheses will be derived to test the relationship between family control, role duality, capital adequacy, board size and earnings management practices.

\subsubsection{Family Control}

Bonnachi et al. (2018, p. 1338) highlight that "the relationship between family ownership and earnings management is an empirical question because the literature provides competing and alternative predictions about the effects of this relationship". In particular, agency problems in family firms differ from those in non-family firm. Concentration of ownership in family firms leads to a new form of conflict of interest; a principal-principal conflict of interests. The dominant majority wishes to achieve its interests at the expense of minority shareholders (Cheng, 2014; Chi et al., 2015). Thus, there are two opposing effects of the impact of family control on earnings management practices: the first is entrenchment of interests and the second is alignment of interests. These effects are explained as follows:

\subsubsection{The Entrenchment Effect}

This effect points to the traditional view that family firms are less effective in control because ownership concentration will create an incentive for the majority owners to control the 
company and to drain the wealth of minority owners (Chi et al., 2015). Dominant family members may gain important positions in the executive management team and BOD. Controlling family has more incentives and ability to achieve more benefits even at the expense of other minority shareholders (Paiva et al., 2019). Consequently, the effect of defending personal interests is expected and family firms will report lower-quality earnings to the benefit of the controlling family (Machiga and Teitel, 2009; Siregar and Utama, 2008; Wang, 2006). In this situation, earnings management is used to mislead financial reporting users and to conceal the opportunistic behavior of the controlling family to harm the interests of the minority shareholders (Prencipe and Bar-Yosef, 2011).

\subsubsection{The Alignment Effect}

This effect indicates the alignment in the interests of the controlling family with the interests of other minority shareholders. The founding family owns a large proportion of the firm's shares and maintain them for a relatively long period of time (Paiva et al., 2019). Users of financial statements demand high quality earnings; especially if they suspect the impact of entrenchment of the controlling family, to protect their investments and interests. The controlling family has an incentive to provide high-quality earnings to protect its reputation and improve the long-term performance of the firm (Chi et al., 2015; Ali et al. 2007; Machuga and Tei, 2006; Wang, 2006). Controlling family can practice more effective monitoring on managers and consequently agency problems, such as divergence of interest, are less significant in family firms compared to non-family firms (Paiva et al., 2019). The controlling family wants to know how their businesses are run and even to participate in managing them and limiting managers' opportunistic decisions, especially as their investments are characterized by lack of diversity and long-term orientation compared to the rest of the owners. It can be expected that in these situations managers will be less motivated to manage earnings to avoid damage to owners (Prencipe and Bar-Yosef, 2011). Also, the wealth of the controlling family is tied to the value of the firm (Wang, 2006). Thus, if family control reflects an efficient organizational structure, family firms will reduce the opportunistic behavior of earnings management (Siregar and Utama, 2008). Finally, Ferramosca and Allegrini (2018) argue that sometimes the entrenchment effect may become an alignment effect when family involvement increases leading to greater monitoring and hence a lower earnings management behavior.

Since the entrenchment effect and the alignment effect operate in opposite directions, the final effect on earnings management is uncertain (Prencipe and Bar-Yosef, 2011). Therefore, the following hypothesis can be stated:

$\mathrm{H}_{1}$ : There is a significant relationship between family control and earnings management practices in Lebanese commercial banks.

\subsubsection{Role Duality}

Agency theory points to the need for having different people in the decision-making function (the executive director) and the decision control function (the chairperson) to limit the executive director's control of the board (Jensen, 1993). Role duality refers to the situation 
where the board chairperson will also act as the chief executive officer (CEO) of the firm. The chairperson functions include managing the work within the board, supervising the recruitment and dismissal process, evaluation the performance of executive management and determining their incentives. It is therefore important to separate the positions of the chairman and CEO, so that the board becomes an effective control mechanism (Prencipe and Bar-Yosef, 2011). This separation of roles will increase the effectiveness of internal control, where no single person will hold sole decision-making power (Chen et al., 2007). The Chairman of the board has strong authority over the BOD, setting the board's agenda and managing board meetings. Thus, dual roles within the board threaten its autonomy (Roodpousthi and Chashmi, 2011). Role duality allows the executive director to restrict the availability of information to board members, which limits effective oversight by the board on executive management. Accordingly, corporate governance rules and recommendations suggest the need to separate roles within the board (Roodpousthi and Chashmi, 2011).

The separation of roles within the BOD will reduce agency problems and harmonize the interests of owners and management (Klein, 2002). It also supports the board's independence and limits the executive director's control of the board (Taktak and Mbarki, 2015; Jouber and Fakhfakh, 2012). Role duality is argued to be associated with high levels of earnings management (Cornett et al., 2009; Mohamad et al., 2012) because it provides greater freedom for executives to practice accounting discretion and manipulating financial reports (Saleh et al., 2005). Klein (2002) argues that the excessive powers of executive directors over the BOD will enable them to exercise earnings management. Based on the above, the following hypothesis can be derived:

$\mathrm{H}_{2}$ : There is a significant negative relationship between role duality in the board of directors and earnings management practices in Lebanese commercial banks.

\subsubsection{Capital Adequacy}

Regulatory bodies may enforce companies in specific industries to meet certain regulatory measures. For example, banking legislations require banks to meet capital adequacy requirements and that insurance companies to meet minimum solvency requirements; both are often determined using accounting data.

Earnings may be managed to avoid the consequences of non-compliance with capital adequacy ratios (Elleuch, 2015). Therefore, there is a need for mechanisms to reduce earnings management practices (Chen at al., 2007), especially as the banking sector is one of the most profitable economic sectors.

A number of studies have tested this motivation in the banking sector. For example, Shrieves and Dahl (2003) study shows that Japanese banks use loan loss provision and investment gains or losses as tools to achieve capital adequacy levels in accordance with Basel Committee's regulatory requirements. In the same context, Anandarajan et al. (2007) argue that Australian banks are also pursuing the same approach. Concerning signaling to capital market participants through discretionary accruals. Shrieves and Dahl (2003) and Beatty et al. (2002) suggest that Japanese and US banks are using loan losses for income smoothing and 
minimizing small declines in earnings; seeking to meet analysts' forecasts or achieving a target earnings. Based on the previous discussion the following hypothesis could be derived.

$\mathrm{H}_{3}$ : There is a significant positive relationship between capital adequacy ratio and earnings management practices in Lebanese commercial banks.

\subsubsection{Board Size}

Accounting research has tended to examine the impact of board characteristics in reducing earnings management practices. These characteristics are found to affect the accounting choice by executive management (Jouber and Fakhfakh, 2012). According to Mohamad et al. (2012), the effectiveness of the BOD in performing its oversight function will be reflected positively in the quality of financial reports. An active board can reduce the opportunistic behavior of managers and thus better protect the owners; especially when compliance with accounting standards is not enough to verify the absence of all forms of manipulation in the financial statements (Saleh et al., 2005).

Internal corporate governance mechanisms such as the board of directors may play an important role in reducing earnings management practices (Chen et al., 2007). Effective control by the BOD is important in reducing the probability of engaging in earnings management (Abdul Rahman and Ali, 2006). Hence, the role of the BOD as an important mechanism of internal corporate governance that aims to control the behavior of executives (Alves, 2011). BOD represents the link between shareholders (capital providers) and managers (capital users) for value creation purposes. It is responsible for monitoring the quality of financial reporting and ensuring that decisions are consistent with the interests of owners, creditors and any other party related to the firm. Especially in the presence of incentives for managers to manage earnings to mislead users of financial statements (Alves, 2010, Dimitropoulos and Asteriou, 2010).

Board size is important variable that affects the board's effectiveness in carrying out its oversight functions (Jensen, 1993). Accounting literature suggests two points of view regarding the relationship between board size and earnings management (Taktak and Mbarki, 2014). On the one hand, Banderilipe (2007) believes that the number of board members must be large enough to carry out oversight functions effectively. Large board size may contain diverse managerial and accounting expertise (Peasnell et al., 2000). This diversity of expertise assists BOD in performing effective monitoring on executive management's performance, and consequently reduces the possibilities of earnings management (Abdul Rahman and Ali, 2006; Xie et al., 2003).

On the other hand, Jensen (1993) believes that a large board is less efficient in achieving coordination, communication and decision-making. In large boards, more control tasks are distributed over a larger number of members, which weakens coordination among them (Vafeas, 2000). As board size increases the likelihood of poor decisions and discussions is increased as well (Yermack, 1996) and the control of CEO over the board is increased which in turn reduces the efficiency of control over executive management (Banderilipe, 2007). Small board is more efficient compared to large board due to its higher level of coordination 
and effective communication between board members (Dimitropoulos and Asteriou, 2010). Alves (2011) asserts that small board is effective in the context of financial reporting, as each member of the BOD will be able to better discharge his/her responsibilities and thus be able to mitigate earnings management due to the better discussions of financial reports among a small number of members. Based on the above, the following non-directional hypothesis can be derived:

$\mathrm{H}_{4}$ : There is a significant relationship between capital adequacy ratio and earnings management practices in Lebanese commercial banks.

\section{Research Design}

This section identifies the study's population and sample (4.1) and discusses the dependent and independent variables measurement (4.2).

\subsection{Population and Sample}

The population for this study consists of Lebanese commercial banks registered with the Banque du Liban during the period 2008-2016. Commercial banks under foreign (including Arab) control were excluded from the sample, taking into account the acquisitions and mergers made during that period. The study period was chosen to cover the period from 2008 to 2016 so that the researchers can test earnings management practices during and after the global financial crisis. This contributes to the literature on earnings management practices during economic crises (Arthur et al., 2015; and Raffournier, 2014). The population for the study includes 187 bank/year from 2008 to 2016. However, five observations are excluded due to incomplete information bringing the final population to 182 observations.

Data related to the financial statements of the Lebanese commercial banks were obtained for estimating the discretionary part of LLP, family control role duality, capital adequacy and BOD size. Data was obtained from the Union of Lebanese Banks and Bank Data enterprise.

\subsection{Dependent Variable Measurement}

Based on previous studies, the relationship between family control, role duality, capital adequacy, BOD size and earnings management will be tested using a two-step approach (Cornett et al., 2009; Kanagaretnam et al., 2010; Leventis and Dimitropoulos, 2012). In the first step, non-discretionary (normal) accruals are estimated in the LLP using regression analysis, where loan losses is the dependent variable and total assets, total non-performing loans, provision for loan losses and loan quality as independent variables. The $\left(\mathrm{e}_{\mathrm{it}}\right)$ in the equation represents the discretionary (abnormal) accruals. The present study uses Beatty et al.'s (2002) model used in Cornett et al. (2009) and Leventis and Dimitropoulos (2012). The model is shown as follows:

$$
\begin{aligned}
\text { LOSS }_{\text {it }} & =a_{t}+b_{1} \text { LnTAit }+b_{2} \text { NPL }_{i t}+b_{3} \text { LLR }_{i t}+b_{4} \text { LOANRET }_{i t}+b_{5} \text { LOANSME }_{i t} \\
& +b_{6} \text { LOANCORP }_{i t}+b_{7} \text { LOANHOUS }_{i t}+b_{8} \text { LOANPUB }_{i t}+b_{9} \text { LOANSEC }_{i t} \\
& +b_{10} \text { LOANOTHR }_{i t}+e_{i t}
\end{aligned}
$$




\section{Ml Macrothink}

Where:

a is regression constant.

b is regression coefficients.

LOSS is the loan loss expense deflated by total loans amount.

LnTA is the natural log of total assets

NPL id the percentage of non-performing loans to total loans.

LLR is the percentage of loan loss provision to total loans.

LOANRET is the percentage of retail loans to total loans.

LOANSME is the percentage of loans to medium and small enterprises to total loans.

LOANCORP is the percentage of loans to corporate sector to total loans.

LOANHOU is the percentage of housing loans to total loans.

LOANPUB is the percentage of public loans to total loans.

LOANSEC is the percentage of secured loans to total loans.

LOANOTHR is the percentage of other loans to total loans.

e is regression error (residual).

The different types of loans were included in estimating the discretionary component of the loan loss expense because the characteristics of the loan portfolio are expected to affect the loan loss expense (Beatty et al., 2002). Different types of loans are included because they represent different credit risk and this may lead to loan losses better reflect the expected differences in loan losses for various loans with different default risks (Wahlen, 1994).

In the second step, the relationship between role duality, family control, capital adequacy, BOD size and absolute values of discretionary accruals $(|\mathrm{EM}|)$ is tested. Absolute values of non-discretionary accruals $(|\mathrm{EM}|)$ is an indicator of earnings management. Absolute values of discretionary accruals are used because the focus of this study is earnings management practices per se, regardless if they represent profit-increasing or profit-decreasing practices (Dimitropoulos and Asteriou, 2010; Jiang et al., 2008; Klien, 2002; Prencipe and Bar-Yosef, 2011; Wang, 2006).

\subsection{Control Variables}

According to the political cost hypothesis, large firms are exposed to more political costs, more media scrutiny and stakeholder control and this reduces the likelihood of their involvement in earnings management (Watts and Zimmerman, 1990). Based on this hypothesis, Cornett et al. (2009) argues that bank size may have a significant impact on earnings management. Large banks are likely to be subject to more regulatory oversight to maintain the safety and security of the banking system. Therefore, large banks will be less 
likely to engage in earnings management practices. Moreover, prior literature indicates that profitability could be a significant determinant of earnings management. Xie et al. (2003) argue that since managers' incentives are based on corporate financial performance, it would be in their interest to show better financial performance through earnings management. However, the direction of the relationship is not clear. From one side, based on the political cost hypothesis, banks may face political pressures from the society and tend to report less profits to legitimize their activities in the society. On the other side, banks may engage in more earnings management practices and tend to report more profits to meets earnings targets.

Furthermore, a dummy variable is added to detect earnings management practices overtime. This assists in capturing period individual-invariant variables such as economic conditions that affect all the companies in the same industry in the same way but may change from year to year (Filip and Raffournier, 2014). Consequently, the regression model includes a dummy variable (YEAR) to capture the effect of changes in economic condition from 2008 to 2016.

\subsection{Regression Model}

Based on the previous discussion, the regression model is shown as follows:

$$
\begin{aligned}
\left|\mathrm{EM}_{\text {it }}\right| & =\mathrm{a}_{\mathrm{t}}+\mathrm{b}_{1} \mathrm{FAM}_{\mathrm{it}} \text { it }+\mathrm{b}_{2} \text { DUAL }_{\mathrm{it}}+\mathrm{b}_{3} \mathrm{CAP}_{\mathrm{it}}++\mathrm{b}_{4} \text { BSIZE }_{\mathrm{it}}+\mathrm{b}_{5} \mathrm{ROA}_{\mathrm{it}} \\
& +\mathrm{b}_{6} \mathrm{SIZE}_{\mathrm{it}}+\mathrm{b}_{7} \text { YEAR }_{\mathrm{it}}+\mathrm{e}_{\mathrm{it}}
\end{aligned}
$$

Where:

|EM it| represents the absolute value of discretionary accruals as a proxy for earnings management.

$\mathbf{F A M}_{\mathbf{i t}}=$ family control is measured by the percentage of board members from the same family to the total number of members on the BOD (Ho and Wong, 2001).

DUAL $_{\text {it }}=$ role duality is measured by a dummy variable that takes the value of 1 if the board chairperson and CEO are the same person and zero otherwise (Abdul Rahman and Ali, 2006; Chi et al., 2015).

$\mathbf{C A P}_{\text {it }}=$ capital adequacy is measured by the percentage of capital adequacy ratio (Ahmed et al., 1999).

BSIZE $_{i \mathbf{t}}=$ size of BOD and is measured by the number of board members (Abdul Rahman and Ali, 2006; Dimitropoulos and Asteriou, 2010).

$\mathbf{R O A}_{i t}=$ bank profitability is measured by return on assets (Leventis and Dimitropoulos, 2012)

SIZE $_{\text {it }}=$ bank size is measured by total assets (Kanagaretnam et al., 2010; Leventis and Dimitropoulos, 2012).

$\mathbf{Y E A R}_{\text {it }}=$ a dummy variable for each year is included which takes the value of 1 for that year and zero otherwise (Leventis and Dimitropoulos, 2012). 


\section{Mll Macrothink}

International Journal of Accounting and Financial Reporting

ISSN 2162-3082

2019, Vol. 9, No. 4

\subsection{Regression Assumptions}

Based on regression plots, the residual plots show approximate linear relationship between dependant variable and independent variables. Therefore, the linearity assumption is not seriously violated since non-linear pattern is not observed. In addition, residual plots report no funnel patterns which support that heteroscedasticity is not a serious problem to regression analysis. In addition, the histogram of residual and P-P plot shows no significant violation to normality assumption. Furthermore, VIF value for all the regressors are below the value of 10 (Table 1) (Field, 2005), the highest VIF is 2.317 for BOD size and hence multicolinearity is not a serious problem to regression analysis. Finally, Durbin-Watson test statistics (Table 1) is 2.321 , which is very close to the cut-off point of 2 indicating the absence of residual autocorrelation problem (Gujarati, 2004). Therefore, it could be concluded that regression assumptions are reasonably satisfied hence the reported results are valid for generalization.

\section{Results and Discussion}

Table (1) reports the outputs of the regression analysis for the association between earnings management (dependant variable), family control, role duality, capital adequacy, board size (independents variables), profitability, bank size and year (control variables). The model as a whole is statistically significant $(\mathrm{F}=10.866, \mathrm{p}<0.01)$. The variations in the independent variables can explain $43.30 \%$ of the variations in earnings management practices in the studied sample.

Table 1. Regression analysis results

Model Summary

Model R R Square Adjusted R Square Std. Error of the Estimate Durbin-Watson

$\begin{array}{lllll}1 & .690 & .477 & .433 & .02405\end{array}$

ANOVA

\begin{tabular}{|c|c|c|c|}
\hline Model & Sum & sdf Mean & Sig. \\
\hline Regressic & n.088 & 14.006 & 10.866 .000 \\
\hline Residual & .097 & 167.001 & \\
\hline Total & .185 & 181 & \\
\hline
\end{tabular}

Coefficients

\begin{tabular}{lllll}
\hline Model & $\begin{array}{l}\text { Unstandardized } \\
\text { Coefficients }\end{array}$ & $\begin{array}{l}\text { Standardized t } \\
\text { Coefficients }\end{array}$ & Sig. & $\begin{array}{l}\text { Collinearity } \\
\text { Statistics }\end{array}$ \\
\hline
\end{tabular}


B Std. Error Beta

Tolerance VIF

\begin{tabular}{|c|c|c|c|c|c|c|c|}
\hline (Constant) & -.040 & .018 & & -2.224 & .027 & & \\
\hline FAM & .070 & .022 & .258 & 3.203 & .002 & .484 & 2.066 \\
\hline DUAL & .001 & .009 & .009 & .163 & .871 & .962 & 1.040 \\
\hline CAP & .002 & .000 & .345 & 5.767 & .000 & .875 & 1.143 \\
\hline BSIZE & .002 & .001 & .147 & 1.728 & .086 & .432 & 2.317 \\
\hline $\mathrm{ROA}$ & .017 & .002 & .447 & 7.579 & .000 & .900 & 1.111 \\
\hline SIZE & -.001 & .003 & -.015 & -.203 & .840 & .592 & 1.688 \\
\hline YEAR 2009 & -.006 & .007 & -.063 & -.849 & .397 & .572 & 1.748 \\
\hline YEAR 2010 & -.003 & .007 & -.031 & -.414 & .679 & .569 & 1.758 \\
\hline YEAR 2011 & -.014 & .008 & -.134 & -1.805 & .073 & .570 & 1.755 \\
\hline YEAR 2012 & -.010 & .008 & -.099 & -1.343 & .181 & .571 & 1.750 \\
\hline YEAR 2013 & -.015 & .008 & -.145 & -1.908 & .058 & .540 & 1.853 \\
\hline YEAR 2014 & -.013 & .008 & -.121 & -1.584 & .115 & .537 & 1.861 \\
\hline YEAR 2015 & -.015 & .008 & -.150 & -1.961 & .052 & .534 & 1.872 \\
\hline YEAR 2016 & -.010 & .008 & -.100 & -1.305 & .194 & .533 & 1.877 \\
\hline
\end{tabular}

Results indicate a significant positive association between the level of family control and earnings management $(\mathrm{p}<0.01)$. This means that companies with high family control level practice more earnings management compared to companies with low family control level. Therefore, $\mathrm{H}_{1}$ is supported. This result supports the entrenchment effect where dominant family members have greater incentives to engage in earnings management to gain more benefits on the account of other shareholders and to conceal their opportunistic behaviour. This result is in accordance with the results of Prencipe and Bar-Yosef (2011), Chi et al. (2015) and Paiva et al. (2019) and in contrast with the result of Wang (2006), Jaggi and Tsui (2007) and Machuga and Teitel (2009). 
Regarding role duality, the result indicates a non-significant association between role duality and earnings management ( $\mathrm{p}>0.10$ ). This result contradicts the expectation of agency theory, which suggests that the separation between CEO position and chair of the board position may mitigate earnings management practices. Therefore, $\mathrm{H} 2$ is not supported. It seems that there are other factors that may limits the ability of CEO and chair of the board to mitigate earnings management such as the power of controlling family which may resist any intervention by the CEO and chair of the board to achieve their own interest. The controlling family work on their own interest regardless whether the authority in centred in one hand (duality situation) or distributed between different hands (none duality situation). This result is in line with the results of Xie et al. (2003), Abdul Rahman and Ali (2006). However, the result in conflicted with the results of Mohamad et al. (2012) and Chi et al. (2015) .

Regarding capital adequacy, the results show a significant positive association between capital adequacy and earnings management $(\mathrm{p}<0.01)$. This means that banks with higher capital adequacy ratio practice more earnings management compare to banks with low capital adequacy ratio. So, $\mathrm{H}_{3}$ is supported. This result support the claim that banks may employ earnings management to comply with the national and international regulatory requirements related to a target level of capital adequacy. This result confirmed the results of Shrieves and Dahl (2003) and Anandarajan et al. (2007).

Regarding board size, the results show a significant positive association between board size and earnings management $(\mathrm{p}<0.10)$. This means that banks with large boards tend to practice more earnings management compare to banks with small board size. So, $\mathrm{H}_{4}$ is supported. This result confirms the claim of Jensen (1993) that a large board is less efficient in achieving coordination, communication and decision-making. In large boards, more control duties are distributed over a large number of members, which weakens coordination among them (Vafeas, 2000). In addition, in large boards, the probability of slow decision-making and useless discussions are increased (Yermack, 1996). Therefore, managers increasingly aim to maximize their personal benefits by involving in earnings management practices (Taktak and Mbarki, 2015). This result is in line with the result of Abdul Rahman and Ali (2006) and Mansor et al. (2013) while contradict with the results of Xie et al. (2003) and Alves (2011).

Regarding the control variables, the result highlights a significant positive association between profitability and earnings management $(\mathrm{p}<0.01)$. This means that banks with higher profitability practice more earnings management compared to banks with low profitability, this results confirms the results of Shrieves and Dahl (2003) and Beatty et al. (2002) that banks use earnings management to smooth their earnings and to meet target profits levels. The results indicate that bank size has non-significant impact on earnings management. This means that bank visibility in terms of bank size is not a determinant of earning management in the Lebanese banking sector. This result may be due to the exposure of Lebanese banks to the same political costs regardless how large is their size. This result contradicts with the result of a number of studies (Alves, 2011; Dimitropoulos and Asteriou, 2009; Jouber and Fakhfakh, 2012). The result regarding earning management over the period 2008 to 2016 indicates that earnings management is practiced on a selective basis based on the 
circumstances and targets to be achieved. It could be argued that Lebanese commercial banks engaged in more earnings management practices in the period after the financial crisis and potentially to be prepared for the application of new international financial reporting standards in 2018.

\section{Conclusion}

This study investigates the effects of family control, role duality, BOD size and capital adequacy on earnings management practices in the banking sector in Lebanon. In the banking sector, earnings management practices were measured by LLP in line with extant literature. Bank managers have some flexibility in determining the level of LLP, which could influence their ability to manage earnings to achieve certain targets. Family control indicates the level of family members' ownership in the bank and its influence on the decisions taken by the board. We are particularly interested in the role duality of the CEO and the bank's chairperson. It was argued that the separation of those two roles increase the effectiveness of controlling the decisions of the board as it reduces potential agency problems and supports board's independence. Finally, capital adequacy was examined in this study to reflect the impact of the compliance with regulatory requirements on managers' motivation and/or ability to manipulate earnings.

Our results show a significant positive impact of family control over the board of directors on earnings management practices in the sample. Family control in the Lebanese banking sector indicates the influence of family owners in manipulating earnings to achieve better results to the family at the expense of other stakeholders. This result may call for banks to develop better governance mechanisms to monitor board decisions where there is a significant impact of family on managerial decision-making.

In addition, we find a positive significant impact of bank's profitability and capital adequacy ratios on earnings management practices. Facing pressures to report higher or lower earnings may lead banks to try to manipulate their reported income to meet public and family expectations. Furthermore, strict regulatory requirements, in the form of capital adequacy ratios, may result in more incentives to manipulate profits. These results may indicate a need for more scrutiny into the banks' reported earnings. Role duality has no impact on earnings management since other power management such as the power of controlling family may limit the ability of CEO and chair of the board to mitigate earnings management. In addition, board size is associated positively with earnings management due to inefficiency of large boards in mitigating earning management. Bank size does not seem to affect earnings management practices. Therefore, it may be assumed that banks of different sizes face similar regulatory and social pressures. Finally, banks manage their earnings on a selective basis where banks seem to manage earnings in the years after the global financial crisis.

This study has three main contributions. First, the study contributes to the literature on earnings management by providing a better understanding of earnings management practices in developing countries (Lebanese) banking sector, thus filling an important research gap in earnings management literature. Second, the focus on one industry provides the ability to define a model that takes into account the characteristics of the industry and therefore has a 
high explanatory power and provides a reliable measure in determining optional entitlements (Key, 1997). Third, this study examines the impact of family control on earnings management and identifies the earnings management behavior during and after the global financial crisis, supporting evidence already introduced by few research efforts in the field.

Future research can compare earnings management in banks with and without family control. In addition, examining the interaction between family control and role duality is another interesting research avenue to be examined by future research. Furthermore, examining family control in non-conventional banks is strongly suggested for future examination.

There are a number of limitations to this study. First, the impact of financial leverage on earnings management practices is beyond the scope of this study. In general, the nature of the banking activity requires a high degree of financial leverage. Second, earnings management behavior in the period prior to the global financial crisis was not studied because the data were not fully available. Third, earnings management is not measured by gains (losses) on investments. Available data does not clearly show the amount of gains (losses) on investments in the financial statements. Consequently, any attempt to estimate the gains (losses) will reply on personal judgment, which may have a negative impact on the validity of research results. Finally, the impact of the audit committees on earnings management practices is also beyond the scope of the study because the Lebanese banking system requires the need for audit committees in all registered banks. Finally, the current study does not address earnings management in non-conventional banks.

\section{References}

Abdelghany, K. E. (2005). Measuring the quality of earnings. Managerial Auditing Journal, 20(9), 1001-1015.

Abdul Rahman, R., \& Ali, F. H. M. (2006). Board, audit committee, culture and earnings management: Malaysian evidence. Managerial Auditing Journal, 21(7), 783-804.

Agarwal, S., Chomsisengphet, S., Liu, C., \& Rhee, S. G. (2007). Earnings management behaviors under different economic environments: Evidence from Japanese banks. International Review of Economics and Finance, 16(3), 429-443.

Ahmed, A. S., Takeda, C., \& Thomas, S. (1999). Bank loan loss provisions: A reexamination of capital management, earnings management and signaling effect. Journal of Accounting and Economics, 28, 1-25.

Al-Fayoumi, N., Abuzayed, B., \& Alexander, D. (2010). Ownership structure and earnings management in Emerging Markets: The case of Jordan. International Research Journal of Finance and Economics, 38, 28-47.

Ali, A., Chen, T.-Y., \& Radhakrishnan, S. (2007). Corporate disclosures by family firms. Journal of Accounting and Economics, 44(1-2), 238-286.

Alves, S. M. G. (2011). The effect of the board structure on earnings management: Evidence from Portugal. Journal of Financial Reporting and Accounting, 9(2), 141-160. 
Anandarajan, A., Hasan, I., \& McCarthy, C. (2007). Use of loan loss provision for capital, earnings amazement and signalling by Australian banks. Accounting and Finance, 47, 357-379.

Argilés-Bosch, J. M., García-Blandón J., \& Martínez-Blasco, M. (2012). Earnings Management Behaviour Under the Recent Economic Downturn in Spain. International Finance Review, 13, 231-255.

Arthur, N., Tang, Q., \& Lin, Z. (2015). Corporate accruals quality during the 2008-2010 Global Financial Crisis. Journal of International Accounting, Auditing and Taxation, 25, $1-15$.

Banderlipe, M. R. S. (2009). The impact of selected corporate governance variables in mitigating earnings management in the Philippines. DLSU Business and Economic Review, $19,17-27$.

Bassemir, M., \& Novotny, F. Z. (2018). IFRS adoption, reporting incentives and financial reporting quality in private firms. Journal of Business Finance \& Accounting, 45(7/8), 759-796.

Beatty, A. L., Ke, B., \& Petroni, K. R. (2002). Earnings management to avoid earnings declines across publicly and privately held banks. The Accounting Review, 77(3), 547-570.

Beneish, M. D. (2001). Earnings management: A perspective. Managerial Finance, 27(12), 3-17.

Bonacchi, M., Cipollini, F., \& Zarowin, P. (2018). Parents' Use of Subsidiaries to "Push Down" Earnings Management: Evidence from Italy. Contemporary Accounting Research, 35(3), 1332-1362.

Chen, K. Y., Elder, R. J., \& Hsieh, Y.-M. (2007). Corporate governance and earnings management: The implications of corporate governance best-practice principles for Taiwanese listed companies. Journal of Contemporary Accounting and Economics, 3(2), 73-105.

Cheng, Q. (2014). Family firm research: A review. China Journal of Accounting Research, 7, 149-163.

Chi, C. W., Hung, K., Cheng, H. W., \& Lieu, P. T. (2015). Family firms and earnings management in Taiwan: The influence of corporate governance. International Review of Economics and Finance, 36, 88-98.

Cornett, M. I., McNutt, J. J., \& Tehranian, H. (2009). Corporate governance and earnings management at large U.S. bank holding companies. Journal of Banking and Finance, 15, 412-430.

DeAngelo, L. E. (1986). Accounting numbers as market valuation substitutes: A study of management buyouts of public stockholders. The Accounting Review, 61(3), 400-420. 


\section{Mll Macrothink}

International Journal of Accounting and Financial Reporting

ISSN 2162-3082

2019, Vol. 9, No. 4

Dechow, P. M., \& Skinner, D. J. (2000). Earnings management, reconciling the views of accounting academics, practitioners, and regulators. Accounting Horizons, 14(2), 235-250.

Dechow, P. M., Sloan, R. G., \& Sweeney, A. P. (1995). Detecting earnings management. The Accounting Review, 70(2), 193-225.

Dechow, P. M., Sloan, R. G., \& Sweeney, A. P. (1996). Causes and consequences of earnings management manipulation: An analysis of firms subject to enforcement actions by the SEC. Contemporary Accounting Research, 13(1), 1-36.

DeFond, M. L., \& Jiambalvo, J. (1994). Debt covenant violation and manipulation of accruals. Journal of Accounting and Economics, 17(1-2), 145-176.

Dimitropoulos, P. E., \& Asteriou, D. (2010). The effect of board composition on the informativeness and quality of annual earnings: Empirical evidence from Greece. Research in International Business and Financ, 24, 190-205.

Duréndez, A., \& Madrid-Guijarro, A. (2018). The impact of family influence on financial reporting quality in small and medium family firms. Journal of Family Business Strategy, 9(3), 205-218.

Elleuch, S. H. (2015). Earnings management and evolution of the banking regulation: The case of Tunisian banks following the IMF recommendations. Journal of Accounting in Emerging Economies, 5(2), 150-169.

Fahed-Sreih, J., Pistrui, D., Huang, W., \& Welsch, H. (2009). Family contributions to entrepreneurial development in Lebanon. International Journal of Organizational Analysis, 17(30), 248-261.

Ferramosca, S., \& Allegrini, M. (2018). The complex role of family involvement in earnings management. Journal of Family Business Strategy, 9(2), 128-141.

Field, A. (2005). Discovering statistics using SPSS. Sage Publications Ltd. London.

Filip, A., \& Raffournier, B. (2014). Financial Crisis And Earnings Management: The European Evidence. The International Journal of Accounting, 49, 455-478.

Gujarati, D. N. (2004). Basic Econometrics. The McGraw-Hill. New York.

Healy, P. M. (1985). The effect of bonus schemes on accounting decisions. Journal of Accounting and Economics, 7(1-3), 85-107.

Healy, P. M., \& Wahlen, J. M. (1999). A review of the earnings management literature and its implications for standard setting. Accounting Horizons, 13(4), 365-383.

Ho, S. S. M., \& Wong, K. S. (2001). A study of the relationship between corporate governance structures and the extent of voluntary disclosure. Journal of International Accounting, Auditing and Taxation, 10, 139-156. 


\section{Macrothink}

International Journal of Accounting and Financial Reporting

ISSN 2162-3082

2019, Vol. 9, No. 4

Ismail, A. G. B., Shaharudin, R. S., \& Samsudhram, A. R. (2005). Do Malaysian banks manage earnings through loan loss provisions?. Journal of Financial Reporting and Accounting, 3(1), 41-47.

Jacoby, G., Li, J., \& Liu M. (2019). Financial distress, political affiliation and earnings management: the case of politically affiliated private firms. The European Journal of Finance, 25(6), 508-523.

Jaggi, B., \& Tsui, J. (2007). Insider trading, earnings management and corporate governance: Empirical evidence based on Hong Kong firms. Journal of International Financial Management and Accounting, 18(3), 192-222.

Jensen, M. C. (1993). The Modern Industrial Revolution, Exit and the Failure of Internal Control Systems. The Journal of Finance, 48(3), 831-880.

Jensen, M. C., \& Meckling, W. H. (1976). Theory of the firm: Managerial behavior, agency costs and ownership structure. Journal of Financial Economics, 3(4), 305-360.

Jiang, W., Lee, P., \& Anandarjan, A. (2008). The association between corporate governance and earnings quality: Further evidence from using the GOV-Score. Advances in Accounting, $24,191-201$

Jones, J. J. (1991). Earnings management during import relief investigations. Journal of Accounting Research, 29(2), 193-228.

Jouber, H., \& Fakhfakh, H. (2012). Earnings management and board oversight: An international comparison. Managerial Auditing Journal, 27(1), 66-86.

Kanagaretnam, K., Lim, C. Y., \& Lobo, G. J. (2010). Auditor reputation and earnings management: International evidence from the banking sector. Journal of Banking and Finance, 34, 2318-2327.

Key, K. G. (1997). Political cost incentives for earnings management in the cable television industry. Journal of Accounting and Economics, 23, 309-337.

Klein, A. (2002). Audit committee, board of director characteristics and earnings management. Journal of Accounting and Economics, 33, 375-400.

Koh, P.-S. (2003). On the association between institutional ownership and aggressive corporate earnings management in Australia. The British Accounting Review, 35, 105-128.

Koumankos, E., Siriopoulos, C., \& Heorgopoulo, A. (2005). Firm acquisitions and earnings management: evidence from Greece. Managerial Auditing Journal, 20(7), 663-678.

Leventis, S., \& Dimitropoulos, P. (2012). The role of corporate governance in earnings management: Experience from US banks. Journal of Applied Accounting Research, 13(2), 161-177.

Liu, Q., \& Lu, Z. (2007). Corporate governance and earnings management on the Chinese listed companies: A tunneling perspective. Journal of Corporate Finance, 13, 881-906. 


\section{Mll Macrothink}

International Journal of Accounting and Financial Reporting

ISSN 2162-3082

2019, Vol. 9, No. 4

Machuga, S., \& Teitel, K. (2009). Board of director characteristics and earnings quality surrounding implementation of a corporate governance code in Mexico. Journal of International Accounting, Auditing and Taxation, (18), 1-13.

Mansor, N., Che-Ahmad, A., Ahmad-Zalki, N. A., \& Osman, A. H. (2013). Corporate governance and earnings management: A study on the Malaysian Family and Non-Family Owned PLC's. Procedia Economics and Finance, 7, 221-229.

McNichols, M. F. (2000). Research design issues in earnings management studies. Journal of Accounting and Public Policy, 19, 313-345.

Mohamad, M. H. S., AbdulRashid, H. M., \& Shawtari, F. A. M. (2012). Corporate governance and earnings management in Malaysian government linked companies. Asian Review of Accounting, 20(3), 241-258.

Nornoha, C., Zeng, Y., \& Vinten, G. (2008). Earnings management in China: An exploratory study. Managerial Auditing Journal, 23(4), 367-385.

Paiva, I. S., Lourenço, I. C., \& Curto, J. D. (2019). Earnings management in family versus non-family firms: the influence of analyst coverage. Spanish Journal of Finance and Accounting, 48(2), 113-133.

Park, Y. W., \& Shin, H. H. (2004). Board composition and earnings management in Canada. Journal of Corporate Finance, 10, 431-457.

Peasnell, K. V., Pope, P. F., \& Young, S. (2000). Accrual management to meet earnings targets: UK evidence pre-and post- Cadbury. British Accounting Review, 32, 415-445.

Prencipe, A., \& Bar-Yosef, S. (2011). Corporate governance and earnings management in family-controlled companies. Journal of Accounting, Auditing and Finance, 26(2), 199-227.

Roodposhti, F. R., \& Chashmi, S. A. N. (2011). The impact of corporate governance mechanisms on earnings management. African Journal of Business Management, 5(11), 4143-4151.

Saleh, N. M., Iskandar, T. M., \& Rahmat, M. M. (2005). Earnings management and board characteristics: Evidence from Malaysia. Jurnal Pengurusan, 24, 77-103.

Schipper, K. (1989). Commentary on earnings management. Accounting Horizons, 3(4), 91-102.

Shrieves, R. E., \& Dahl, D. (2003). Discretionary accounting and the behavior of Japanese banks under financial duress. Journal of Banking and Finance, 27, 1219-1243.

Siregar, S. V., \& Utama, S. (2008). Types of earnings management and the effect of ownership structure, firm size, and corporate governance practices: Evidence from Indonesia. The International Journal of Accounting, 43, 1-27. 


\section{MlMacrothink}

International Journal of Accounting and Financial Reporting

ISSN 2162-3082

2019, Vol. 9, No. 4

Taktak, N. B., \& Mbarki, I. (2014). Board characteristics, external auditing quality and earnings management: Evidence from the Tunisian banks. Journal of Accounting in Emerging Economies, 4(1), 79-96.

Vafeas, N. (2000). Board structure and the informativeness of earnings. Journal of Accounting and Public Polic, 19(2), 139-160.

Wahlen, J. M. (1994). The nature of information in commercial bank loan loss disclosures. The Accounting Review, 69(3), 455-478.

Wang, D. (2006). Founding family ownership and earnings quality. Journal of Accounting Research, 44(3), 619-656.

Watts, R. L., \& Zimmerman, J. L. (1990). Positive accounting theory: A ten year perspective. The Accounting Review, 65(1), 131-156.

World Bank. (2003). Lebanon - Report on the Observance of Standards and Codes (ROSC) accounting and auditing. Washington, DC. World Bank.

Xie, B., Davidson, W. N., \& DaDalt, P. J. (2003). Earnings management and corporate governance: The role of the board and the audit committee. Journal of Corporate Finance, 9, 295-316.

Yermack, D. (1996). Higher market valuation of companies with a small board of directors. Journal of Financial Economics, 40(2), 185-211.

Yung, K., \& Root, A. (2019). Policy uncertainty and earnings management: International evidence. Journal of Business Research, 100, 255-267

\section{Copyright Disclaimer}

Copyright for this article is retained by the author(s), with first publication rights granted to the journal.

This is an open-access article distributed under the terms and conditions of the Creative Commons Attribution license (http://creativecommons.org/licenses/by/4.0/) 